\title{
The Bosna River floods in May 2014
}

\author{
Andrej Vidmar ${ }^{1}$, Lidija Globevnik ${ }^{1}$, Maja Koprivšek ${ }^{1}$, Matej Sečnik ${ }^{1}$, Katarina Zabret $^{1}$, Blažo Đuroviće,a, \\ Darko Anzeljc $^{2, a}$, Janez Kastelic ${ }^{3}$, Mira Kobold ${ }^{3}$, Mojca Sušnik ${ }^{3}$, Darko Borojevič ${ }^{4}$, Tarik Kupusovićc \\ Esena Kupusović ${ }^{6}$, Anja Vihar $^{1}$, and Mitja Brilly ${ }^{1}$ \\ ${ }^{1}$ Faculty of Civil and Geodetic Engineering, University of Ljubljana, 1000 Ljubljana, Slovenia \\ ${ }^{2}$ Institute for Water of the Republic of Slovenia, 1000 Ljubljana, Slovenia \\ ${ }^{3}$ Slovenian Environment Agency, 1000 Ljubljana, Slovenia \\ ${ }^{4}$ RHMZ RS, 78000 Banja Luka, Bosnia and Herzegovina \\ ${ }^{5}$ HEIS, 71000 Sarajevo, Bosnia and Herzegovina \\ ${ }^{6}$ FHMZ FBiH, 71000 Sarajevo, Bosnia and Herzegovina \\ ${ }^{a}$ now at: The Slovenian Water Agency, 1000 Ljubljana, Slovenia
}

Correspondence to: Mitja Brilly (mbrilly@fgg.uni-lj.si)

Received: 23 June 2015 - Published in Nat. Hazards Earth Syst. Sci. Discuss.: 29 October 2015

Revised: 15 September 2016 - Accepted: 19 September 2016 - Published: 10 October 2016

\begin{abstract}
In May 2014, extreme floods occurred in the lower Sava River basin, causing major damage, with catastrophic consequences. Based on the data gathered, the weather situation in Bosnia and Herzegovina's (BiH) Bosna River basin was analysed and the hydrological conditions were provided, including the results of the probability analysis of the size of the recorded precipitation and flow rates. According to the observed data, extremely high precipitation intensities produced specific discharges of $1.0 \mathrm{~m}^{3} \mathrm{~s}^{-1} \mathrm{~km}^{-2}$. A hydrological model of the Bosna River basin was developed using HBV light for the purposes of reconstructing and forecasting such events more effectively. All analyses confirmed that the May 2014 event was an extreme extraordinary event whose return period greatly exceeds 100 years. The study is the basis for further flood safety measures and flood forecast development in the Bosna River basin.
\end{abstract}

\section{Introduction}

Devastating floods are a rare and unique phenomenon that prompts an in-depth hydrological analysis. This may involve the use of various statistical analysis tools, including hydrological modelling (Atta ur and Khan, 2013; Faisal et al., 2003; Grillakis et al., 2010; Silvestro et al., 2012).

This paper will address the May 2014 flooding of the Bosna River. The Bosna River basin (Fig. 1) comprises
$10420 \mathrm{~km}^{2}$ according to the orographic boundary (ZV and FHMZ, 2012). The river, whose headwaters are in the Dinaric Mountains with peaks rising more than $2000 \mathrm{~m}$ above sea level, flows from the south to the north. Next to Sarajevo, the capital of $\mathrm{BiH}$, which is situated in the Bosna River headwaters, there are important industrial towns located along its main channel: Zenica, Zavidovići, Maglaj, Doboj, Modriča, and Šamac - the latter at the confluence of the Bosna and Sava rivers.

In May 2014, flooding occurred because of precipitation that continuously fell for 4 days over the Sava River and its lower reach tributaries in the territories of Croatia, Bosnia and Herzegovina $(\mathrm{BiH})$, and Serbia. The floods caused $23 \mathrm{fa}-$ talities, while more than 100000 people were displaced from their homes, and many landslides and debris flows affected the area. All told, the flood event affected more than $50 \%$ of $\mathrm{BiH}$ territory. The total estimated losses and damages, based on the recovery needs assessment, were almost EUR 2 billion (BiH, EU, UN, WB, 2014).

As is usually the case in such extreme hydrological events, water also damaged the hydrometric stations. It was those very stations which were to record the extremely high water levels that were particularly damaged or destroyed. Therefore, a hydrological model was produced and employed in the analysis. 


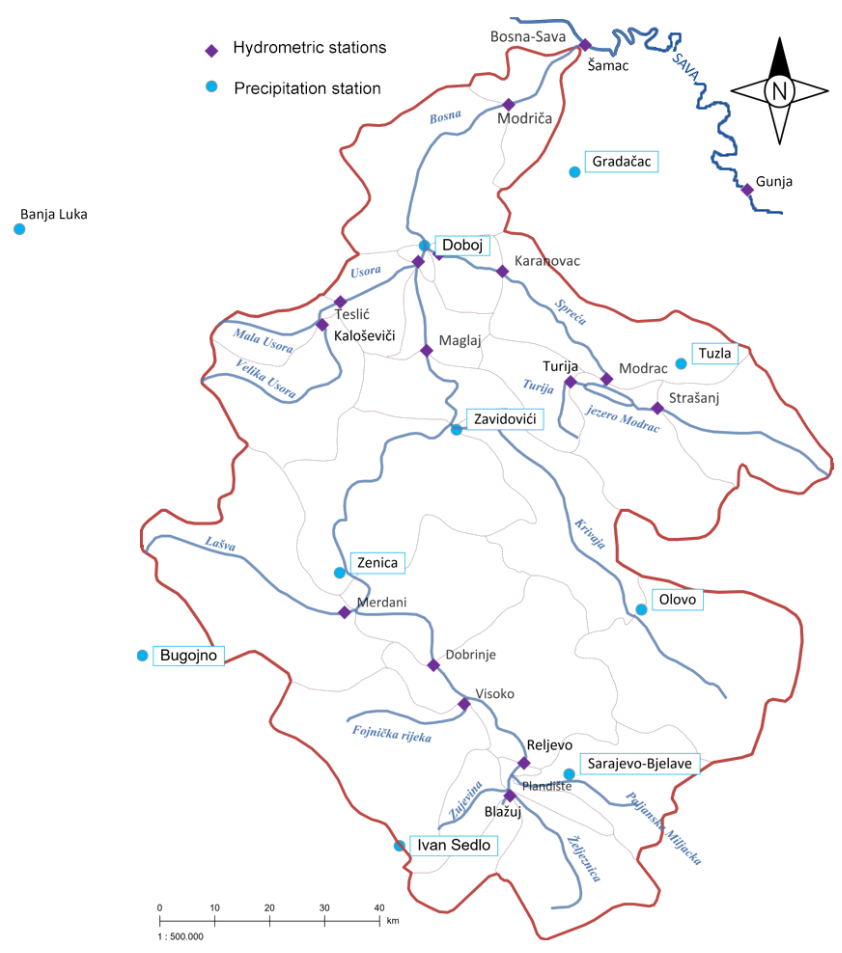

Figure 1. The Bosna River basin with major tributaries, locations of hydrometric stations, and precipitation stations ( $\mathrm{ZV}$ and FHMZ, 2012).

\section{Description of weather conditions}

The May 2014 floods in the Balkans were the consequence of extraordinary precipitation due to the extensive low-pressure area, which moved from the South Adriatic Sea across Bosnia and Herzegovina and Serbia to Hungary. Even before the flood event, the soil in the flooded area was saturated due to the heavy rainfall in April, with the highest monthly rainfall amount recorded since 1961 at the weather stations Banja Luka with $214 \mathrm{~mm}$, Tuzla $193 \mathrm{~mm}$, and Zavidovići $170 \mathrm{~mm}$, respectively (Table 1). At some weather stations, there was more than double the average historical rainfall for April. In April, Bosnia and Herzegovina was hit by as many as seven cyclones, while already on 2 May a new upper-level low formed over the Gulf of Genoa, which caused excessive rainfall on 3 and 4 May, particularly in the north (RHMZ RS, 2014).

On Monday 12 May 2014, a cold front passed through the affected zone, which brought in cooler air, particularly in the atmosphere's upper layers. By early Wednesday morning, a shallow low-pressure area had formed above the territory and began to intensify (DHMZ, 2014). From the west, upper-level jet streams brought in moist and unstable air. The inflow of cold air across the Alps on Wednesday 14 May caused a huge cyclone to form with its centre over Bosnia and Herzegovina. The cyclone reached its peak on 15 and 16 May when the centre moved towards the northeast, and it was only on Saturday 17 May, when it weakened. This resulted in prolonged rainfall in $\mathrm{BiH}$, Croatia, and Serbia. The cyclone picked up moisture in the Mediterranean Sea and the Black Sea, while at high altitudes the cool air led to snowfall. The processes in the deep cyclone were very intensive since the cyclone's axis was vertical. Additionally, the cyclone was stationary, while on 15 May it moved further west. In addition to the extreme rainfall, the situation deteriorated due to the seasonally unusually low temperatures and severe winds (Renko, 2014). The cyclone took 3 days to pass through the central Balkans. At the same time, the high-pressure area persisted over western Europe and part of central Europe.

The precipitation period started in April 2014 and continued through May, reaching its maximum between 13 and 16 May 2014, as shown in Table 1.

The highest amount of precipitation from 12 to 17 May was recorded in Tuzla $(252 \mathrm{~mm})$, followed by Gradačac $(195 \mathrm{~mm})$ and Olovo $(172 \mathrm{~mm})$. The precipitation recorded in Sarajevo was lower than in the central and eastern part of the basin, but still significant, as precipitation fell across the entire river basin with a relatively moderate intensity. Hourly precipitation data for 15 May in Zenica ranged between 0.7 and $10.7 \mathrm{~mm}$. Sarajevo had the highest intensity of hourly precipitation, where $11.4 \mathrm{~mm}$ of rain fell per hour on 14 May. It rained continuously from 12:00 on 13 May until the early morning of 16 May. Then, over the course of 16 and 17 May, the rain settled down to a very moderate intensity. In Tuzla, $229.9 \mathrm{~mm}$ of rain fell during the $62 \mathrm{~h}$ of continuous precipitation. Moreover, between 13 and 16 May, the snow that fell in the mountains in April, or before, probably also melted because the $0^{\circ} \mathrm{C}$ isoline was at $800 \mathrm{~m}$ a.s.l. in the mountain region during night-time.

\section{Probability analysis of multi-day precipitation in May 2014}

By comparing the probability analysis values of maximum 2 , $3,4,5,10,30,40$, and 50 day precipitation during the 1960 2013 and 2000-2010 periods and the maximum multi-day precipitation in April and May 2014, the May 2014 event return period was estimated for each of the $\mathrm{BiH}$ precipitation stations considered. The analysis included the reports (FHMZ BiH and RHMZ RS, 2014; RHMZ RS, 2014) and some precipitation data published on websites (OGIMET, 2014; Tutiempo, 2014; METEOBLUE, 2014). The data on wind speed recorded at weather stations show very low speed not exceeding $7.1 \mathrm{~m} \mathrm{~s}^{-1}$, so the losses in precipitation recording at the stations did not exceed $10 \%$. Eleven precipitation stations were analysed, for which historical daily precipitation data and the data on precipitation in April and May 2014 were available (Fig. 1). Geographical coordinates (locations), altitudes of stations, and periods of data availability are shown in Table 2. 
Table 1. The daily precipitation and daily precipitation totals for the selected period at individual stations in millimetres (data source: FHMZ BiH, RHMZ RS).

\begin{tabular}{lrrrrrrr}
\hline & $\begin{array}{r}\text { Sarajevo-Bjelave } \\
(\mathrm{mm})\end{array}$ & Olovo & Zenica & Zavidovići & Gradačac & Tuzla & Modrac \\
\hline 1-30 Apr 2014 & 97 & 136.5 & 19.6 & 170 & & 192.6 & \\
1-11 May 2014 & 32 & 27.1 & 16.5 & 25.8 & 91.8 & 55 & \\
12 May 2014 & 14.1 & 15.3 & 4.4 & 0.8 & 3.3 & 4.9 & \\
13 May 2014 & 34.6 & 5.5 & 30.2 & 12.3 & 21.1 & 20.6 & 52 \\
14 May 2014 & 71.3 & 72.9 & 53.7 & 57.1 & 68.3 & 92.3 & 79.5 \\
15 May 2014 & 18 & 65.8 & 38.7 & 33.1 & 85.1 & 103.8 & 76.6 \\
16 May 2014 & 4.6 & 8 & 11.4 & 9 & 13.6 & 28.6 & 14.4 \\
17 May 2014 & 2.4 & 4.4 & 3.3 & 2.4 & 3.3 & 2.5 & \\
13-16 May 2014 & 116.5 & 150.4 & 127.1 & 107.8 & 178 & 229.2 & \\
12-17 May 2014 & 145 & 171.9 & 141.7 & 114.7 & 194.7 & 252.7 & 222.5 \\
1-17 May 2014 & 177 & 156.6 & 274.6 & 113.9 & 382.8 & 247.8 & \\
1 Apr-17 May 2014 & 274 & 335.5 & 293.2 & 310.5 & 286.5 & 500.3 & \\
Yearly average 1961-1990 & 932 & & 782 & & & 894 & \\
\hline
\end{tabular}

For most stations, the data are available for more than 40 years, while for precipitation stations Olovo, Zavidovići, and Sokolac the data are available for only 8 or 11 years. When using the data sets ranging between 40 and 54 years, the results indicate a return period of approx. 200 years. The acquired higher return periods of multi-daily precipitation at these stations, or at the stations with the data sets no longer than 11 years, must be taken with caution. Precipitation distribution at precipitation stations in the selected periods in May 2014 is shown in Table 3.

Return periods for individual precipitation durations are determined using the Gumbel distribution function; see Table 4. Plots of return period isolines for the individual durations of maximum multi-day precipitation also show the estimates of spatial dimension of precipitation event intensity. The 1, 2, 3, 5, 10, 30, 40 and 50 day precipitation return periods in the selected precipitation stations are spatially interpolated using the inverse distance weighted method (Anzeljc and Đurović, 2014). The 1 and 2 day isolines are shown in Fig. 2a and b. Most 1 day precipitation has a 5- to 10-year return period, and in some points a 100-year return period; 2 and 5 day precipitation has in some points a 5000- to 10000 year return period, and 30 day precipitation has a 1000-year return period in some points. Given the precipitation that occurred in more than half of the Bosna River basin, the event probability was between 100 and 200 years, and locally even more than 5000 years.

We find that in Tuzla, most of the multi-day precipitation reached a return period in excess of 500 years. In Olovo, 2 and 3 day precipitation had more than a 500-year return period, while 1, 4 or 30 day precipitation had a 100-year return period. All other precipitation events had a return period of 20 years or more. In Doboj, most instances of multi-day precipitation had a return period between 20 and 50 years, and 3 day precipitation a return period of over 100 years. Sim- ilarly, in Sarajevo and Zenica multi-day precipitation had a return period of more than 20 years, while 3 to 7 day precipitation had a return period of more than 100 years.

In Tuzla, maximum 3 day precipitation fell on 14 May 2014, and 4 day and 5 day precipitation on 13 and 12 May, respectively; the 2 day precipitation in Olovo had a 500-year return period on 14 May; and the 4 day precipitation in Sarajevo had a 100-year return period on 12 May, and in Zenica on 13 May. Given the precipitation that occurred in more than half of the Bosna River basin, the event probability was between 100 and 200 years, and locally even more than 500 years.

\section{Hydrological description of the Bosna River Basin}

The hydrological study report ("Hidrološke studije površinskih voda Bosne i Hercegovine, Sliv rijeke Bosne", ZV, FHMZ BiH, 2012) compiles all the data available for the Bosna River basin. The central part of the Bosna River basin is hilly, while its lower reach flows on floodplains of the Sava River; see Fig. 3. Geologically the basin is extremely versatile, with distinct karst areas in its western part with rather undefined catchment borders. The Bosna River headwaters are defined by the Vrelo Bosne spring with its karst setting and with a small surface stream. Downstream, the Fojnica River and the Lašva River are its left-bank tributaries, while the Krivaja River joins it from the right at Zavidovići; see Fig. 1. At Doboj, the Usora River flows into the Bosna from the left side, and the Spreča River from the right. In the section between the Miljacka and Krivaja tributaries, there are many small streams flowing into the Bosna from the right with catchment areas of up to $200 \mathrm{~km}^{2}$, and a total catchment area of approx. $1700 \mathrm{~km}^{2}$; see Table 5 . The river basin is mostly covered in forest, i.e. more than $56 \%$; see Fig. 4. 


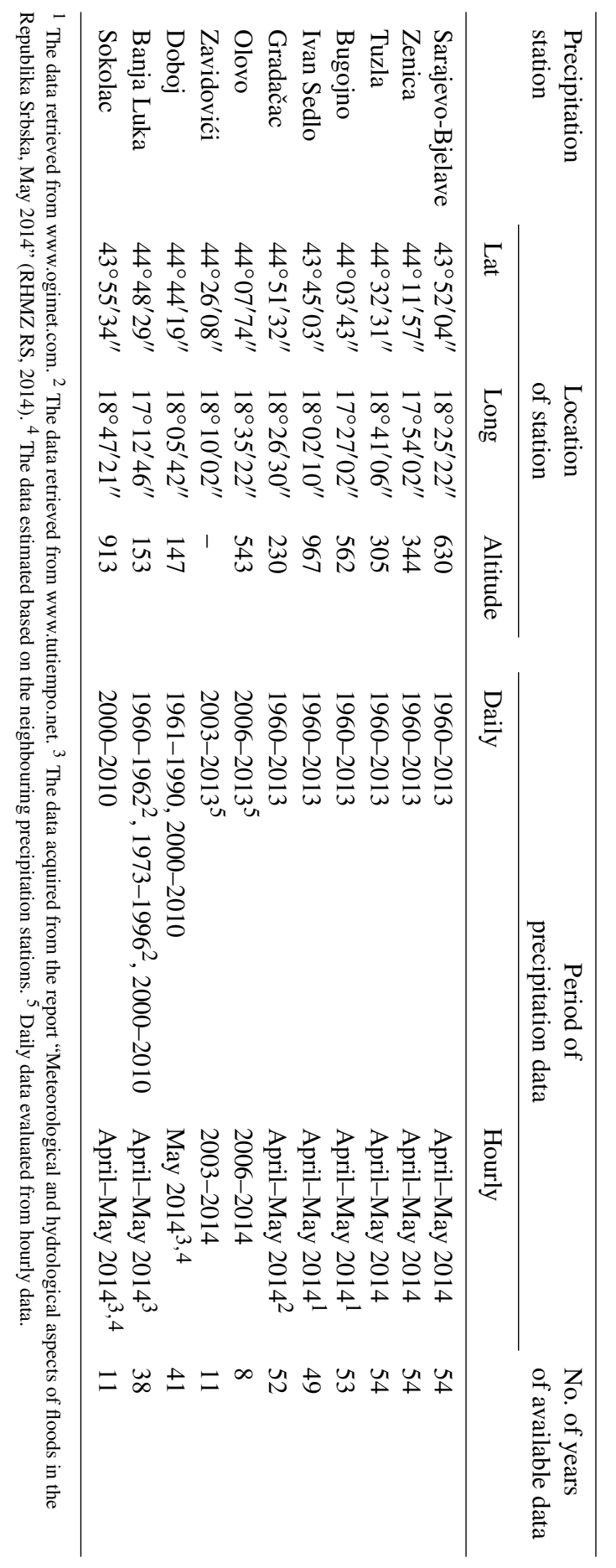

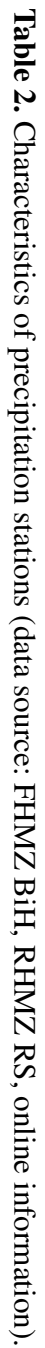

(a)
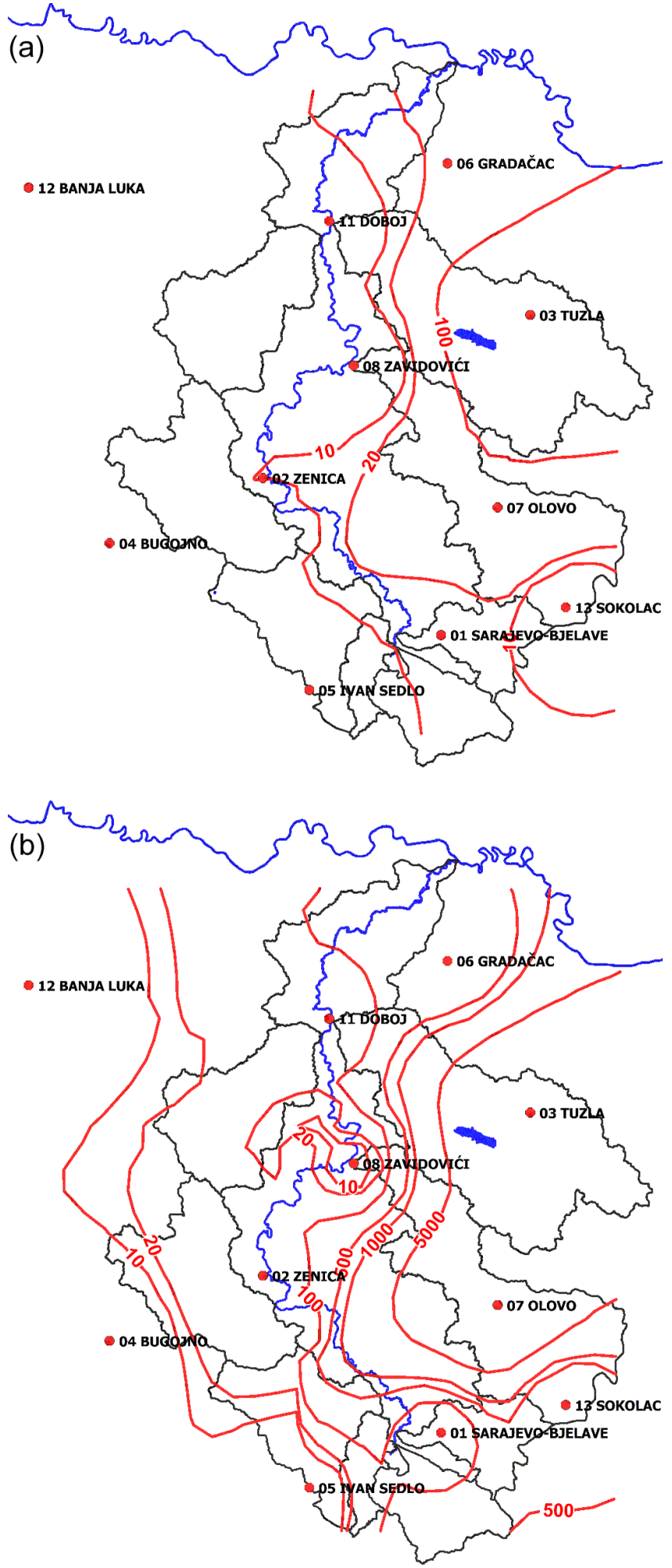

Figure 2. (a) The return period isolines of the 1 day maximum. (b) The return period isolines of the 2 day maximum, May 2014 . 
Table 3. Distribution of precipitation at precipitation stations in the selected periods in April and May 2014.

\begin{tabular}{lrrrrr}
\hline Precipitation station & \multicolumn{5}{c}{ Total precipitation in the period (mm) } \\
\cline { 2 - 6 } & 1-30 Apr 2014 & 1-17 May 2014 & 1 Apr-17 May 2014 & 1-31 May 2014 & 1 Apr-31 May 2014 \\
& 30 days & 17 days & 17 days & 31 days & 61 days \\
\hline Sarajevo-Bjelave & 97.0 & 177.0 & 274.0 & 184.4 & 281.4 \\
Zenica & 19.6 & 158.2 & 177.8 & 184.7 & 204.3 \\
Tuzla & 192.6 & 307.7 & 500.3 & 333.4 & 526.0 \\
Bugojno & 152.8 & 95.0 & 247.8 & 95.8 & 248.6 \\
Ivan Sedlo & 105.9 & 151.1 & 257.0 & 151.1 & 257.0 \\
Gradačac & 145.0 & 286.5 & 431.5 & 301.7 & 446.7 \\
Olovo & 136.5 & 199.0 & 335.5 & 210.5 & 347.0 \\
Zavidovići & 170.0 & 140.5 & 310.5 & 140.5 & 310.5 \\
Doboj & - & 232.5 & 232.5 & 232.5 & 232.5 \\
Banja Luka & 214.0 & 206.0 & 420.0 & 210.0 & 424.0 \\
Sokolac & 155.0 & 211.4 & 366.4 & 219.4 & 374.4 \\
Modrac & 160.8 & 297.8 & 458.6 & 328.8 & 489.6 \\
\hline
\end{tabular}

Table 4. The estimated return periods of multi-day precipitation in April and May 2014 (according to the period 1960-2013).

\begin{tabular}{|c|c|c|c|c|c|c|c|c|c|c|c|c|c|c|c|c|c|}
\hline \multirow{2}{*}{$\begin{array}{l}\text { Precipitation } \\
\text { station }\end{array}$} & \multirow{2}{*}{$\begin{array}{l}\text { No. of } \\
\text { years }\end{array}$} & \multicolumn{16}{|c|}{ Multi-day precipitation (No. of days), return period (yea } \\
\hline & & 1 & 2 & 3 & 4 & 5 & 6 & 7 & 8 & 9 & 10 & 15 & 20 & 30 & 40 & $\mathbf{5 0}$ & 60 \\
\hline $\begin{array}{l}\text { Sarajevo- } \\
\text { Bjelave }\end{array}$ & $54 / 54$ & 10 & 20 & 50 & 100 & 100 & 50 & 20 & 20 & 20 & 10 & 10 & 20 & 20 & 10 & 5 & 5 \\
\hline Zenica & $54 / 54$ & 10 & 50 & 200 & 200 & 200 & 100 & 100 & 50 & 50 & 50 & 25 & 20 & 10 & 5 & 5 & 2 \\
\hline Tuzla & $54 / 54$ & 200 & 10000 & 10000 & 10000 & 10000 & 10000 & 2000 & 2000 & 500 & 500 & 500 & 1000 & 2000 & 500 & 200 & 200 \\
\hline Bugojno & $53 / 54$ & 2 & 2 & 5 & 2 & 2 & 2 & 2 & 2 & 5 & 2 & 5 & 5 & 10 & 10 & 5 & 5 \\
\hline Ivan Sedlo & $49 / 54$ & 5 & 5 & 5 & 5 & 5 & 5 & 2 & 2 & 2 & 2 & 2 & 2 & 2 & 2 & 2 & 2 \\
\hline Gradačac & $52 / 54$ & 20 & 200 & 200 & 200 & 200 & 100 & 100 & 50 & 50 & 50 & 200 & 200 & 500 & 200 & 100 & 50 \\
\hline Olovo & $8 / 54$ & 100 & 10000 & 500 & 200 & 50 & 50 & 50 & 25 & 25 & 25 & 50 & 50 & 100 & 50 & 50 & 25 \\
\hline Zavidovići & $11 / 54$ & 5 & 5 & 10 & 10 & 10 & 10 & 10 & 5 & 5 & 5 & 10 & 5 & 20 & 20 & 10 & 5 \\
\hline Doboj & $41 / 54$ & 5 & 25 & 100 & 50 & 50 & 25 & 20 & 20 & 20 & 20 & 50 & 20 & 10 & 5 & 5 & 20 \\
\hline Banja Luka & $38 / 54$ & 2 & 2 & 5 & 5 & 5 & 5 & 5 & 5 & 5 & 5 & 10 & 20 & 50 & 50 & 50 & 20 \\
\hline Sokolac & $11 / 54$ & 5 & 100 & 200 & 200 & 200 & 200 & 100 & 50 & 50 & 50 & 25 & 50 & 200 & 100 & 25 & 25 \\
\hline \multicolumn{18}{|c|}{ Note: the shading of the values above indicates the ranking of the precipitation return period } \\
\hline \multicolumn{3}{|c|}{\begin{tabular}{l|l} 
& $500-10000$ \\
\end{tabular}} & \multicolumn{5}{|c|}{$100-200$} & \multicolumn{5}{|c|}{\begin{tabular}{|c|}
$20-50$ \\
\end{tabular}} & \multicolumn{5}{|c|}{$2-10$} \\
\hline
\end{tabular}

All hydrometric stations in the river basin are also shown in Fig. 1. The flow measurement data are given in the report (Kastelic et al., 2014), which is a good basis for further hydrological analysis and insight in the Bosna River hydrological system. Furthermore, the data on the January 2010 flood are of interest. At the time, the hourly flow data were available; see Fig. 5. The data and Fig. 5 show that the 2010 flood wave was formed due to the coincidence of the flood wave peaks of the Bosna and the Krivaja at the confluence at Zavidovići. The Lašva River maximum flow occurred more than $40 \mathrm{~h}$ after the first flood peak in the Bosna River at Zavidovići. The data for the Usora River has no significant reaction on the flood event but there were also no data $24 \mathrm{~h}$ after the peak flow in the Bosna River at Zavidovići hydrometric station. Due to the influence of the Modrac reservoir and the extensive floodplain area, the Spreča River flow is almost fully balanced without significant changes. The flood discharges in the main stream of the Bosna River collect runoff from the head part of the catchment, upstream from the hydrometric station Dobrinje, from small tributaries close to the main stream and from the Krivaja River. Discharges rise simultaneously along the river with a concentration time from 6 to $12 \mathrm{~h}$. The tributaries from the karst region, the Lašva River, the Usora River, and the Spreča River with a large reservoir and inundated areas, have concentration times from 1 to 2 days. 


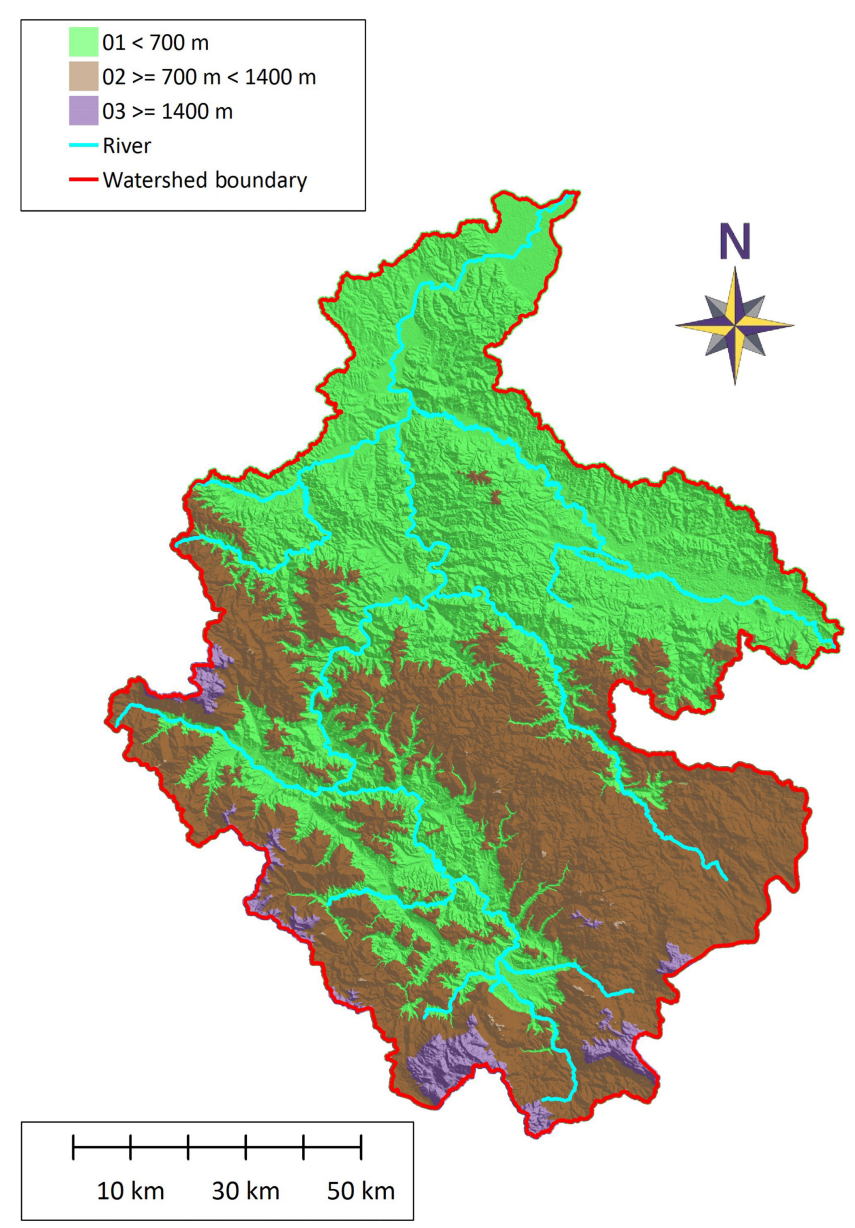

Figure 3. Elevation zones of the Bosna River basin.

This analysis also highlights the complexity of the Bosna River hydrological system. The maximum flows are subject to the coincidence of flood waves and precipitation duration, or are under strong influence of the river basin's karstic region. This phenomenon can be well observed from the Lašva River flows, which during the first flood wave (7 January 2010) did not significantly increase, while its relatively small flood wave coincided with that of the Bosna River. During the second event, the flows significantly increased, culminating in a flood wave that reached the Bosna River channel $10 \mathrm{~h}$ prior to the flood wave peak in the Bosna itself.

\section{Flood in May 2014}

The April and May precipitation caused several flood waves in the Bosna River basin. The maximum flows occurred on 15 May. Figure 6 shows the flood wave discharges during the May 2014 floods at hydrometric stations on the Bosna River and its major tributaries. The data show how the flood wave formed along the Bosna River flow, together with an almost simultaneous increase in discharges. The left tributaries

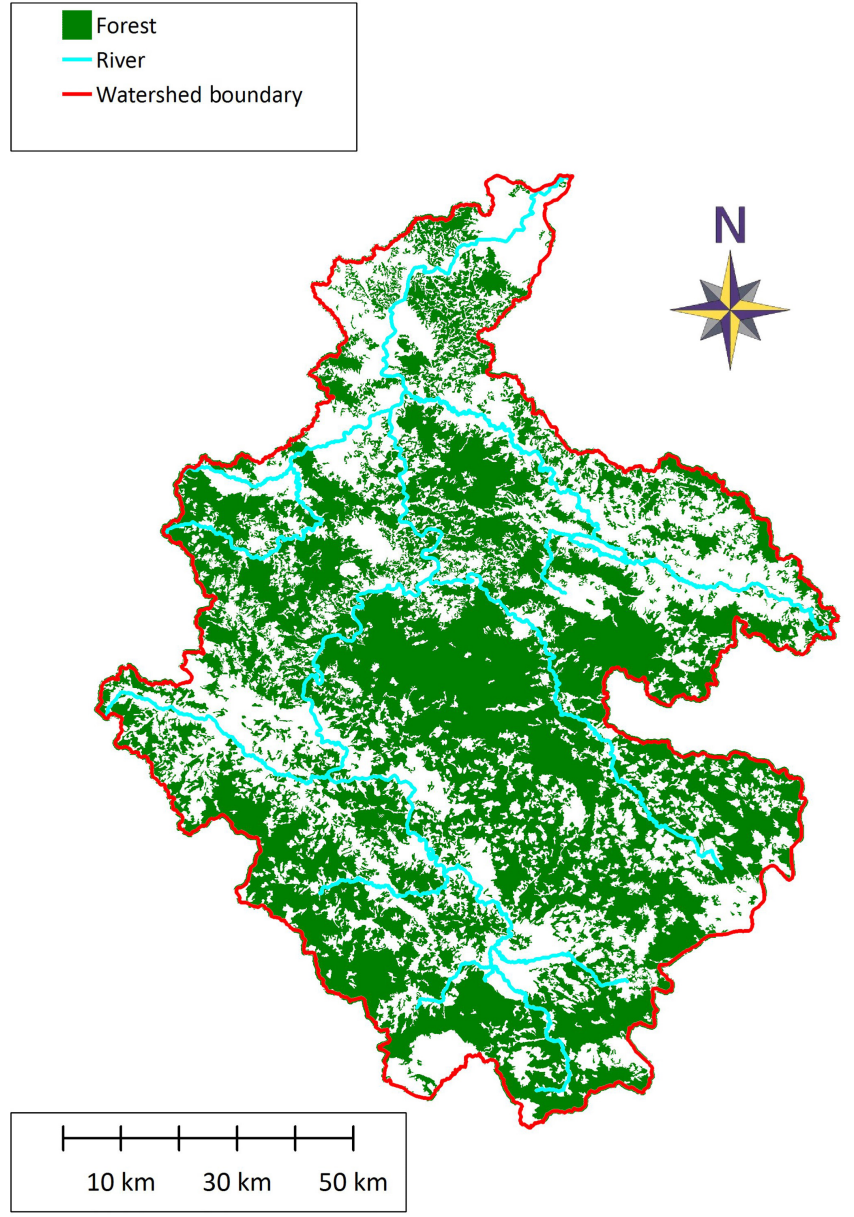

Figure 4. Forest zone in green in the area of the Bosna River basin.

of the Bosna, i.e. the Lašva and Usora rivers, whose recharge area is karst, increased very slowly and reached their maxima when most of the flood wave had already run off. The Krivaja River increased simultaneously and significantly contributed to maximum flows. The Spreča River flows were small due to the retention of water in the Modrac reservoir and the impact of the extensive flooded area which slowed down the rising of flows; in fact, the flows decreased by more than $50 \%$. The Modrac reservoir has a capacity of 68 million $\mathrm{m}^{3}$ and collects water from an area of $1189 \mathrm{~km}^{2}$; flows into the reservoir are very well monitored (Spreča d.d. Tuzla, 2014); see Fig. 7. The diagram shows that the reservoir reduced the discharge from 1602 and $1441 \mathrm{~m}^{3} \mathrm{~s}^{-1}$ to a maximum of $1137 \mathrm{~m}^{3} \mathrm{~s}^{-1}$ and delayed the maximum flow by $10 \mathrm{~h}$. The specific discharges at the reservoir section were around $1 \mathrm{~m}^{3} \mathrm{~s}^{-1} \mathrm{~km}^{-2}$. The flooded area of the Spreča River further decreased the river discharge at the confluence with the Bosna River to only $496 \mathrm{~m}^{3} \mathrm{~s}^{-1}$ and delayed the discharge peak by $11 \mathrm{~h}$. Hence, maximum flows were formed by the tributaries in the upper reach, from the areas whose smaller streams directly joined the Bosna River and its tributary, the Krivaja River. Land- 


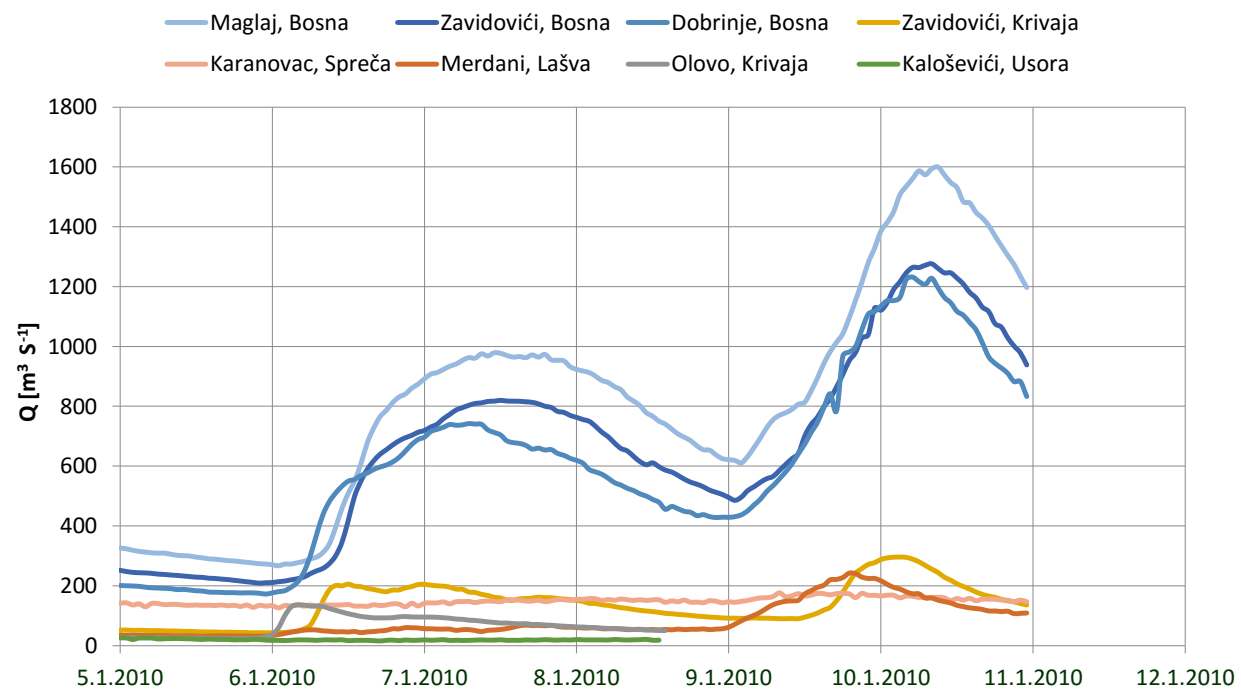

Figure 5. The discharges at hydrometric stations during the January 2010 flooding (data source: FHMZ BiH, 2014).

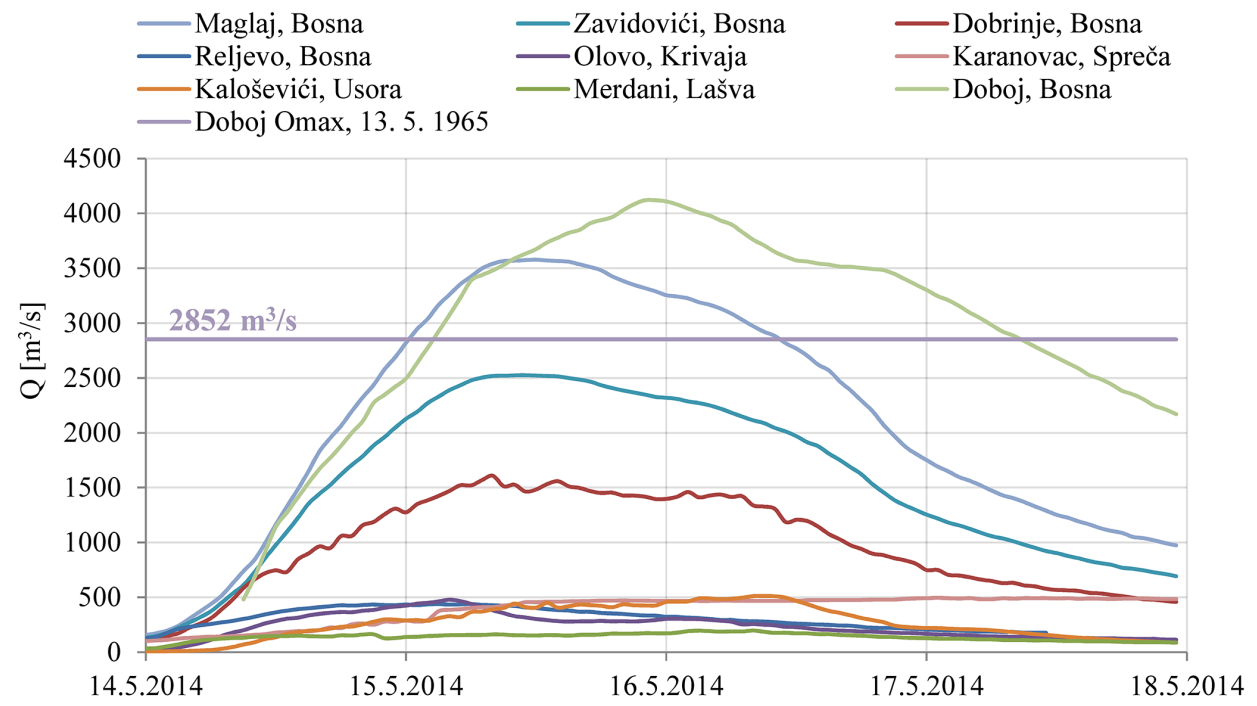

Figure 6. The discharges at hydrometric stations during the May 2014 flooding (data source: RHMZ RS and FHMZ BiH).

slides and debris flows completely altered the morphology of the Željezno polje valley in a part of the Bosna River basin between Zavidovići and Zenica; see Fig. 8.

The hydrometric stations at the Krivaja and Bosna rivers downstream of Doboj were damaged or destroyed. The hydrograph of the Bosna River at hydrometric station Doboj was reconstructed and estimated from observations during the flood event.

The Sava at Bosanski Šamac, i.e. the Bosna River's discharge, started to increase on 14 May and reached its maximum when a flow of $6009 \mathrm{~m}^{3} \mathrm{~s}^{-1}$ was recorded under the Sava bridge. At the same time, at the Gunja hydrometric station downstream from the confluence with the Bosna River, a flow of $4621 \mathrm{~m}^{3} \mathrm{~s}^{-1}$ was recorded, meaning that the floodplain areas upstream from Šamac continued to fill with water.
The recordings were taken by the Croatian hydrometeorological service on 17 May - 1 day after the Bosna River reached its maximum at Doboj (Abdulaj et al., 2014). At the confluence, catastrophic floods occurred due to the water overtopping the embankments on both sides of the Sava, both in $\mathrm{BiH}$ and Croatia.

We analysed the probabilities of annual maximum flows and annual maximum flood wave volumes ${ }^{1}$ of the Bosna River at the hydrometric station Doboj for the 1961-2014 period (the data from 1990 to 1999 are missing) using the Log-Pearson III distribution (Fig. 9, USWRC, 1982). The maximum flow of the Bosna at Doboj in May 2014 was $4121 \mathrm{~m}^{3} \mathrm{~s}^{-1}$ and had a return period of 152 years according

\footnotetext{
${ }^{1}$ The database is available on request.
} 


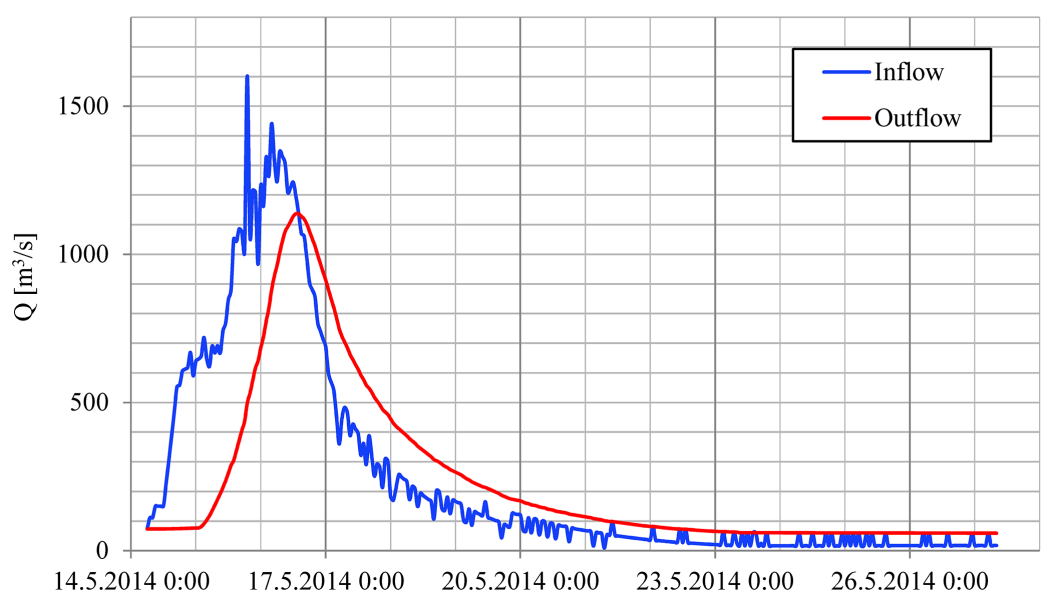

Figure 7. Inflow and outflow diagrams for the Modrac reservoir (data source: Spreča d.d. Tuzla, 2014).

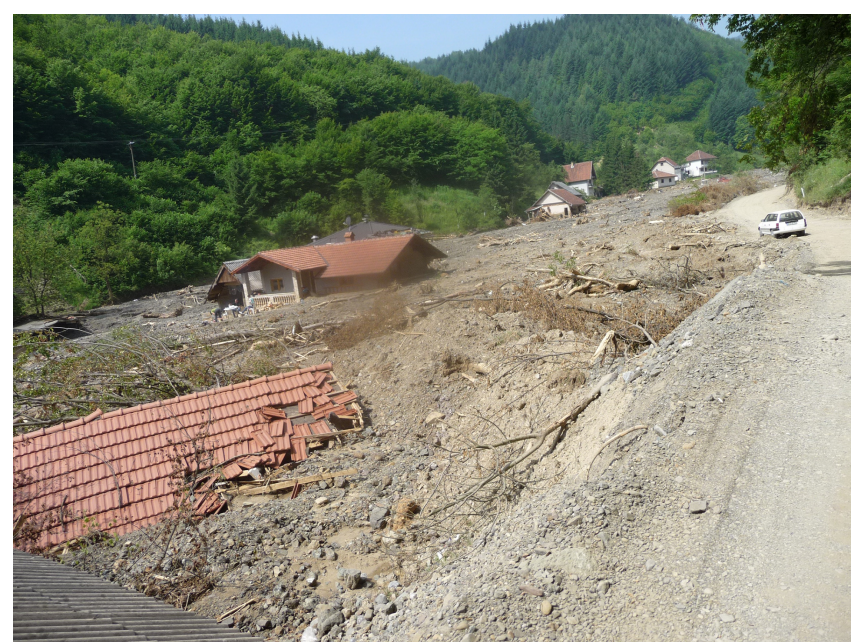

Figure 8. Željezno polje - the consequences of the debris flow.

to the estimated flow probability for the 1961-2014 period. The maximum flood wave volume of the Bosna at Doboj in May 2014 was 1464 million $\mathrm{m}^{3}$ and had a return period of 189 years according to the estimated volume probability for the 1961-2014 period. The maximum recorded flow of the Bosna at Doboj prior to the May 2014 event was $2852 \mathrm{~m}^{3} \mathrm{~s}^{-1}$, and the maximum recorded flood wave volume was 789 million $\mathrm{m}^{3}$.

The data in Table 6 show that at other stations the flows also greatly exceeded the 100 -year return period flows. The flood duration was important, as the maximum flow recorded at hydrometric station Doboj in 1965 , i.e. $2852 \mathrm{~m}^{3} \mathrm{~s}^{-1}$, lasted for more than $55 \mathrm{~h}$ in the 2014 flood.

\section{Hydrological model of the Bosna River}

We developed a hydrological model of the Bosna River for analysis of the 2014 flood. We used HBV light (Seibert, 2005) and PEST model calibration software (Doherty, 2012, 2005; Lawrence et al., 2009; Zhulu, 2010). The Bosna River catchment area was divided into 25 subcatchments with surface areas ranging from 30 to $1000 \mathrm{~km}^{2}$ (Fig. 10). Land use was set according to the CORINE database (Fig. 4) (EEA, 2014). All subcatchments were divided into zones according to altitude (three zones). The height zones were below 700 , from 700 to 1400 , and above $1400 \mathrm{~m}$ (Fig. 3).

The data necessary for model construction were provided by the national hydrological services, which conducted a very good hydrological study of the entire basin by compiling all the recorded hydrological data and fundamental hydrological analyses to date (FHMZ BiH, RHMZ RS, 2014). The available data were mainly collected on a daily step basis.

The precipitation data were collected for six weather stations: Sarajevo-Bjelave, Zenica, Tuzla, Bugojno, Ivan Sedlo, and Doboj. For the same stations, we also considered the data on temperature and evapotranspiration. Data from 31 hydrometric stations were available for modelling. The period of 1 January 1964-31 December 1968 was chosen as the calibration period, and the later period, i.e. 1 January 198431 December 1988, was chosen as the validation period. The calibration period was selected with the highest discharges observed in 1965. Due to the huge discrepancy between the measured and the simulated mass balance, we had to increase the huge karst spring of the Vrelo Bosne river basin (3) from 4 to $169 \mathrm{~km}^{2}$ (Table 6). The river basins of Željeznica and Zujevina were correspondingly reduced. Even with such an extension in the river basin surface, the runoff coefficient of the Vrelo Bosne watershed is among the highest; see Table 6.

The coefficients of determination and efficiency are extremely good for the flows along the Bosna River, and some- 

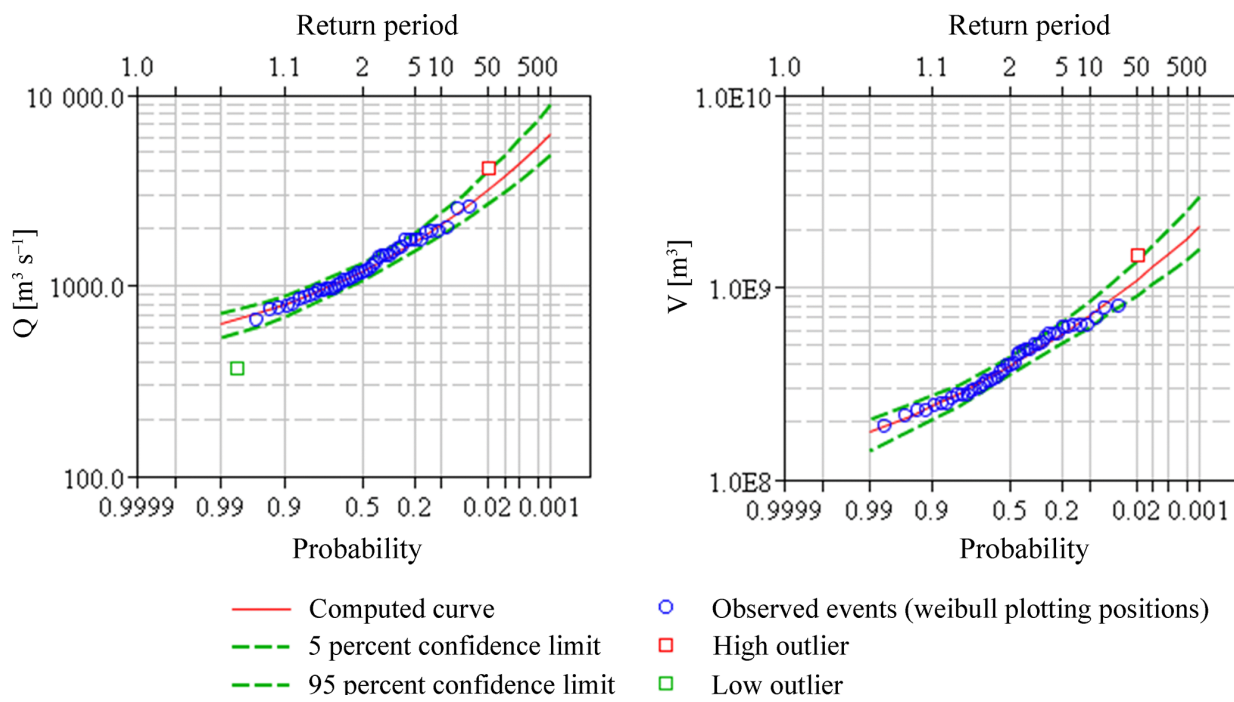

Figure 9. The probability analysis of annual maximum flows and maximum flood wave volumes of the Bosna at Doboj for the 1961-2014 period.

Table 5. Subcatchments with areas used in the hydrological model.

\begin{tabular}{rllr}
\hline $\begin{array}{r}\text { Subcatchment } \\
\text { no. }\end{array}$ & nubcatchment & Watercourse & $\begin{array}{r}\text { Subcatchment } \\
\text { area }\left(\mathrm{km}^{2}\right)\end{array}$ \\
\hline 1 & Željeznica & Željeznica & 433.43 \\
2 & Zujevina & Zujevina & 155.19 \\
3 & Vrelo Bosne & Bosna & 169.14 \\
4 & Miljacka & Miljacka & 412.91 \\
5 & Bosna1 & Bosna & 84.13 \\
6 & Fojnica & Fojnica & 729.36 \\
7 & Bosna2 & Bosna & 773.76 \\
8 & Lašva & Lašva & 958.18 \\
9 & Bosna3 & Bosna & 518.46 \\
10 & Bioštica i Stupčanica & Krivaja & 890.73 \\
11 & Krivaja & Krivaja & 603.42 \\
12 & Bosna4 & Bosna & 892.00 \\
13 & V_Usora & Usora & 480.72 \\
14 & M_Usora & Usora & 158.93 \\
15 & Usora & Usora & 206.72 \\
16 & Bosna5 & Bosna & 266.34 \\
17 & Turija & Turija & 233.03 \\
18 & Spreča1 & Spreča & 463.30 \\
19 & Modrac & Spreča & 495.87 \\
20 & Spreča2 & Spreča & 596.49 \\
21 & Spreča3 & Spreča & 160.10 \\
22 & Bosna6 & Bosna & 182.29 \\
23 & Bosna7 & Bosna & 29.38 \\
24 & Bosna8 & Bosna & 690.79 \\
25 & Bosna9 & Bosna & 251.54 \\
\hline & & Total area & 10836.20 \\
\hline & & & \\
\hline & & & \\
\hline
\end{tabular}


Table 6. Maximum flow probability at selected hydrometric stations (data source: ZV, FHMZ BiH, 2012).

\begin{tabular}{rrrrrrrr}
\hline Return period & \multicolumn{7}{c}{$Q\left(\mathrm{~m}^{3} \mathrm{~s}^{-1}\right)$} \\
\cline { 2 - 8 } & Modriča & Doboj & Maglaj & Zavidovići & Raspotočje & Dobrinje & Reljevo \\
\hline 10 & 2214 & 2091 & 1508 & 1164 & 904 & 600 & 345 \\
20 & 2551 & 2420 & 1764 & 1320 & 1039 & 717 & 400 \\
50 & 2990 & 2795 & 2120 & 1520 & 1220 & 880 & 464 \\
100 & 3318 & 3087 & 2479 & 1673 & 1360 & 1058 & 510 \\
2014 event & & 4121 & 3578 & 2525 & & 1608 & 440 \\
\hline
\end{tabular}

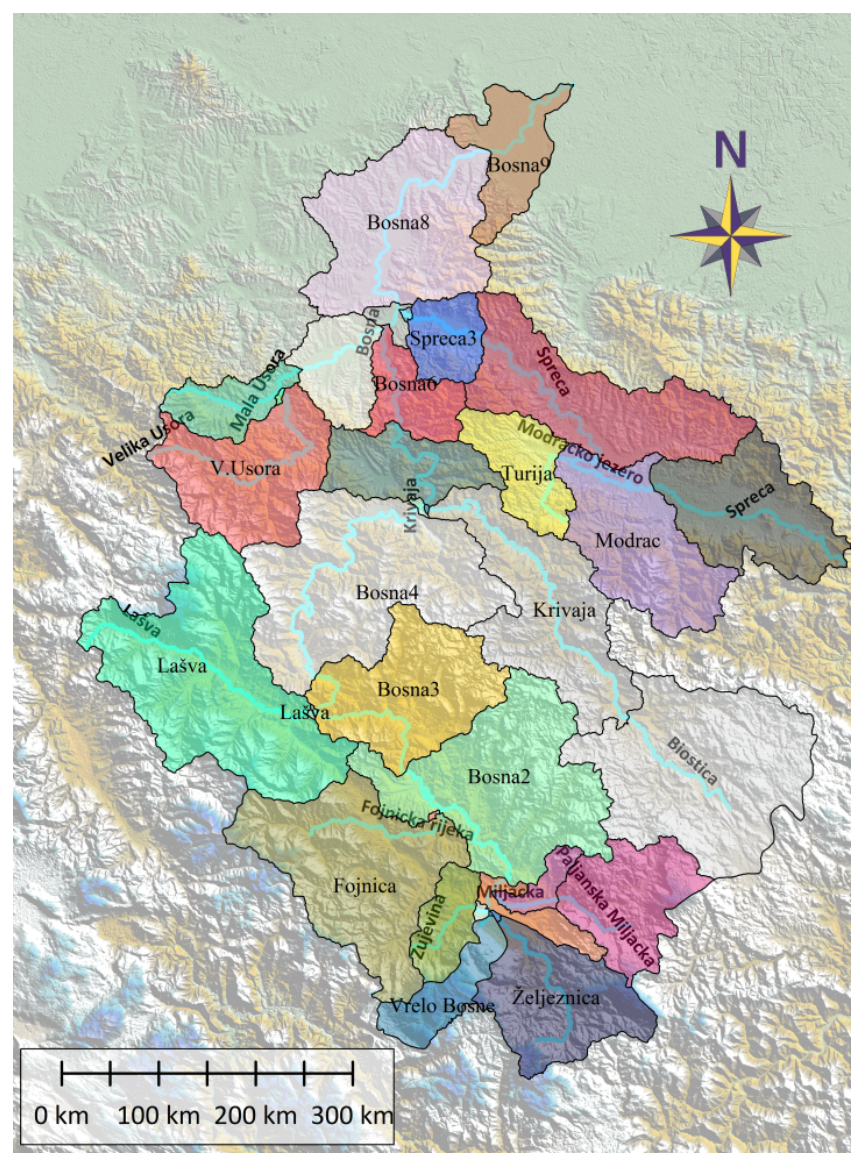

Figure 10. Hydrological model of the Bosna River basin divided into 25 subcatchments.

what poorer for individual tributaries where the precipitation runoff is retained due to the karst geology or the reservoirs. These are the Fojnica, Lašva, Upper Krivaja, Usora, Turija, and Spreča rivers. The model's results show that the catchment area of the Vrelo Bosne (3) is probably still underestimated, while those of the Krivaja River at Olovo and the Lašva River are overestimated; see Table 7. The May 2014 flooding event was simulated using a daily time step for the April-May 2014 period. In Fig. 11 just this flood event is presented. Modelled extremely high flows take 3 days like the measured one (Fig. 6). Discharges reached their max-

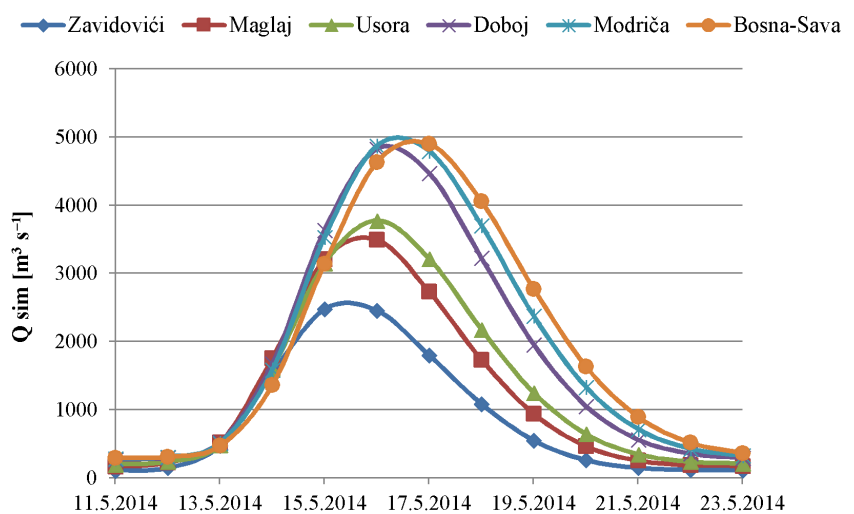

Figure 11. Simulated mean daily discharges on the Bosna River.

ima in Doboj on 16 May and at the confluence with the Sava River, the next day, on 17 May. High discharges simulated by the model were a little higher than the estimated one due to the improper simulation of the release of water in inundated areas. The runoff coefficients for the maximum flood wave in May for the Bosna ranged between 0.76 (Bosna River at Modriča water station) and 0.91 (Bosna River downstream confluence with the Usora tributary). The runoff coefficient for the Bosna at the town of Doboj was 0.82 (Kastelic et al., 2014).

\section{Conclusions}

The precipitation that caused the May 2014 floods of the Bosna River in some places and for 2 day duration exceeded the 5000-year return period. The maximum Bosna River flows at Doboj only reached a 152-year return period, while the flood wave volumes had a somewhat longer return period of 189 years.

The hydrological analyses performed show such a hydrological structure of the basin where the flood wave is formed, mainly in the central part of the river basin, and the Krivaja River tributary and rise simultaneously. The model simulated flood events with proper timing of discharges. The peaks seem a little overestimated. The model clearly presents that the catchment borders should be rearranged due to the karst geology of watershed. The recorded maximum flows 
Table 7. The results of the model calibration with PEST software.

\begin{tabular}{|c|c|c|c|c|c|c|}
\hline \multirow[t]{2}{*}{ Hydrometric station } & \multirow[t]{2}{*}{ Subcatchment } & \multicolumn{5}{|c|}{ The calibration of the model for the period 1 Jan 1961-31 Dec 1990} \\
\hline & & $\begin{array}{l}\text { Coefficient of } \\
\text { determination }\end{array}$ & $\begin{array}{r}\text { Model } \\
\text { effectiveness }\end{array}$ & $\begin{array}{l}\text { Spearman } \\
\text { coefficient }\end{array}$ & $\begin{array}{r}\text { Runoff coefficient } \\
- \text { measured }\end{array}$ & $\begin{array}{r}\text { Runoff coefficient } \\
- \text { simulated }\end{array}$ \\
\hline Ilidža & Željeznica & 0.63 & 0.63 & 0.9 & 0.76 & 0.70 \\
\hline Blažuj & Zujevina & 0.62 & 0.62 & 0.8 & 0.54 & 0.55 \\
\hline Plandište & Vrelo Bosne & 0.75 & 0.75 & 0.9 & 0.82 & 0.82 \\
\hline Sarajevo & Miljacka & 0.58 & 0.58 & 0.8 & 0.55 & 0.52 \\
\hline Reljevo & Bosna1 & 0.73 & 0.72 & 0.9 & 0.79 & 0.77 \\
\hline Visoko & Fojnica & 0.71 & 0.71 & 0.9 & 0.57 & 0.55 \\
\hline Dobrinje & Bosna2 & 0.77 & 0.77 & 0.9 & 0.66 & 0.68 \\
\hline Merdani & Lašva & 0.65 & 0.64 & 0.9 & 0.70 & 0.67 \\
\hline Raspotočje & Bosna3 & 0.80 & 0.80 & 0.9 & 0.73 & 0.74 \\
\hline Olovo & Bioštica & 0.52 & 0.52 & 0.8 & 0.42 & 0.40 \\
\hline Zavidovići_K & Krivaja & 0.61 & 0.61 & 0.8 & 0.59 & 0.59 \\
\hline Zavidovići_B & Bosna4 & 0.77 & 0.76 & 0.9 & 0.77 & 0.77 \\
\hline Teslić & V.Usora & 0.46 & 0.46 & 0.7 & 0.82 & 0.82 \\
\hline Kaloševići & M.Usora & 0.47 & 0.47 & 0.7 & 0.75 & 0.77 \\
\hline Usora-Bosna & Usora & 0.46 & 0.46 & 0.7 & 0.75 & 0.74 \\
\hline Maglaj & Bosna5 & 0.75 & 0.74 & 0.9 & 0.65 & 0.67 \\
\hline Turija & Turija & 0.36 & 0.35 & 0.6 & 0.43 & 0.45 \\
\hline Strašanj & Spreca1 & 0.51 & 0.50 & 0.8 & 0.47 & 0.45 \\
\hline Modrac & Modrac & 0.54 & 0.54 & 0.7 & 0.43 & 0.45 \\
\hline Karanovac & Spreca2 & 0.60 & 0.60 & 0.8 & 0.45 & 0.45 \\
\hline Stanić Rijeka & Spreca3 & 0.65 & 0.64 & 0.8 & 0.69 & 0.44 \\
\hline
\end{tabular}

of the Bosna River in the flood event significantly exceeded the probability of a 100-year return period, while the hydrological model verified such discharges. The flood discharge on water station Doboj in May 2014 was $44 \%$ higher than any previous recorded flow, and insufficiently designed levees collapsed, resulting in fatalities.

The analysis is the basis for further flood safety measures and flood forecast development in the Bosna River basin. The model should be developed on an hourly timescale and used for hydrological forecasting of floods on the Bosna River.

The flow recording data suggest the extreme impact of the reservoir and the Spreča River flooded area on the reduction of the flood wave peak that dropped from 1500 to $500 \mathrm{~m}^{3} \mathrm{~s}^{-1}$. In addition, the recorded specific discharge of $1.0 \mathrm{~m}^{3} \mathrm{~s}^{-1} \mathrm{~km}^{-2}$ is significantly high. Such extreme flood events are rare and we could learn a lot by analysing them.

Each occurrence of extreme floods is complex and the result of the coincidence of various factors. To be able to understand it, a proper data analysis and simulations with wellcalibrated models are necessary.

\section{Data availability}

Data are available upon request from public official institutions: Federal Hydrometeorological Institute BiH and Republic Hydrometeorological Service of RS.
Acknowledgements. These studies were supported by the Slovenian government and conducted in close collaboration with the hydrometeorological services of $\mathrm{BiH}$, which provided the hydrological data and actively participated in their analyses.

Edited by: K. Schröter

Reviewed by: O. Bonacci and two anonymous referees

\section{References}

Abdulaj, R., Miković, N., Oskoruš, D., and Vujnović, T.: Velike vode donjeg toka rijeke save tijekom svibnja 2014, Hrvatska vodoprivreda, 207, 14-16, 2014.

Anzeljc, D. and Đurović, B.: Analiza večdnevnih padavin, ki so maja 2014 povzročile poplave na porečju Bosne: report, Institute for Water of the Republic of Slovenia, Ljubljana, 2014.

Atta ur, R. and Khan, A. N.: Analysis of 2010-flood causes, nature and magnitude in the Khyber Pakhtunkhwa, Pakistan, Nat. Hazards, 66, 887-904, 2013.

$\mathrm{BiH}, \mathrm{EU}, \mathrm{UN}, \mathrm{WB}$ : Bosnia and Herzegovina recovery needs assessment, Floods 14-19 May, available at: http://europa.ba/ documents/delegacijaEU_2014070913592248eng.pdf (last access: 17 September 2014), 2014.

DHMZ: Stoljetna poplava na donjem toku rijeke Save, Meteorological and Hydrological Institute of Croatia, Zagreb, 2014.

Doherty, J.: PEST, Model-Independent Parameter Estimation, User Manual, 5th Edn., Brisbane, Water Numerical Computing, 2005.

Doherty, J.: Addendum to the PEST Manual, Brisbane, Australia, Water Numerical Computing, 2012. 
EEA: CORINE Land Cover. European Environment Agency, Commission of the European Communities, 2014.

Faisal, I. M., Kabir, M. R., and Nishat, A.: The disastrous flood of 1998 and long term mitigation strategies for Dhaka City, Nat. Hazards, 28, 85-99, 2003.

FHMZ BiH and RHMZ RS: Urne in dnevne padavine, temperature, evapotranspiracija za različna obdobja in meteorološke postaje ter njihova lokacija, Federal Hydrometeorological Institute BiH, Sarajevo, 2014.

Grillakis, M. G., Tsanis, I. K., and Koutroulis, A. G.: Application of the HBV hydrological model in a flash flood case in Slovenia, Nat. Hazards Earth Syst. Sci., 10, 2713-2725, doi:10.5194/nhess-10-2713-2010, 2010.

Kastelic, J., Kobold, M., Sušnik, M., Brilly, M., Vidmar, A., Globevnik, L., Koprivšek, M., Sečnik, M., Zabret, K., Šubelj, G., Đurović, B., and Anzeljc, D.: Analiza poplavnega dogodka maja 2014 v Bosni in Hercegovini za porečje reke Bosne: report, University of Ljubljana, Faculty of Civil and Geodetic Engineering, Institute for Water of the Republic of Slovenia, Ljubljana, 2014.

Lawrence, D., Haddeland, I., Langsholt, E., Calibration of HBV hydrological models using PEST parameter estimation. Oslo, Norwegian Water Resources and Energy Directorate: 44 p., 2009.

METEOBLUE: Precipitation data, available at: https://www. meteoblue.com/en/bosnia-and-herzegovina/weather-zavidovi\% C4\%87i/archive, last access: 10 July 2014.

OGIMET: Precipitation data, available at: http://www.ogimet.com/ resynops.phtml.en, last access: 10 July 2014.

Renko, T.: Rekordne količine kiša u Slavoniji i regiji, Hrvatska vodoprivreda, 207, 12-13, 2014.
RHMZ RS: Meteorološki i hidrološki aspekti poplava u Republici Srpskoj, maj 2014, Republic Hydrometeorological Service of RS, Banja Luka, 2014.

Seibert, J.: HBV light version 2, User's manual, Stockholm, Stockholm University, Department of Physical Geography and Quaternary Geology, 2005.

Silvestro, F., Gabellani, S., Giannoni, F., Parodi, A., Rebora, N., Rudari, R., and Siccardi, F.: A hydrological analysis of the 4 November 2011 event in Genoa, Nat. Hazards Earth Syst. Sci., 12, 2743-2752, doi:10.5194/nhess-12-2743-2012, 2012.

Spreča d.d. Tuzla: Javno preduzeće za vodoprivrednu djelatnost "Spreča“ d.d. Tuzla. Data on discharges, water levels and precipitation at the site of HE Modrac for the period February to May 2014, Information on HE Modrac, 2014.

TUTIEMPO: Precipitation data, available at: http://www.tutiempo. net/en/Climate/Banja_Luka/01-1973/132420.htm, last access: 10 July 2014.

USWRC (United States. Interagency Advisory Committee on Water Data. Hydrology Subcommittee): 1982. Guidelines for determining flood flow frequency. Reston, VA: US Department of the Interior, Geological Survey, Office of Water Data Coordination, available at: http://water.usgs.gov/osw/bulletin17b/dl_flow. pdf (last access: 30 September 2016), 1982.

Zhulu, L.: Getting Started with PEST, Athens, The University of Georgia, 28 pp., 2010.

ZV and FHMZ: Hidrološka studija površinskih voda Bosne i Hercegovine, Sliv rijeke Bosne. Institute for Water Management, Federal Hydrometeorological Institute BiH, Sarajevo, 2012. 